\title{
TINJAUAN KRIMINOLOGIS TERHADAP KEGIATAN PRAKTIK PROSTITUSI DI KOTA MAKASSAR
}

\author{
Pambudi Putra Yahya ${ }^{1}$, Kaharuddin ${ }^{2}$ dan Zainudin Bin Hassan ${ }^{3}$ \\ 1Pendidikan Sosiologi, Universitas Muhammadiyah Makassar \\ Email: pambudi@gmail.com \\ ${ }^{2}$ Pendidikan Sosiologi, Universitas Muhammadiyah Makassar \\ Email: kaharuddin@unismuh.ac.id \\ ${ }^{3}$ Pendidikan Sosiologi, Universitas Muhammadiyah Makassar \\ Email: p zainudin@utm.ac.id
}

\begin{abstract}
This study aims to determine the causes of women selling themselves as commercial sex workers, the impact of the existence of commercial sex workers in the area of Jl. Abu Bakar Lambogo and how the government's efforts in overcoming prostitution on Jl. Abu Bakar Lambogo. This type of research is descriptive qualitative research using data collection techniques through observation, interviews and documentation. The data analysis technique used is qualitatively descriptive. This analysis is done by compiling and reducing data, displaying the data collected. Based on the results of the research obtained, it can be concluded that (i) The factors that cause women to sell themselves as commercial sex workers are social environment factors, namely free promiscuity because of the absence of education and fall into employment as sex workers, economic factors, namely lack of income and narrow employment the broken home factor factor is that the family does not get along like a fight and the like causes the child to be neglected or the absence of a parent's function on the child. (ii) Impact of the existence of commercial sex workers in the area of Jl. Abu Bakar Lambogo is a local community who is anxious about the existence of commercial sex workers in the neighborhood around his residence and has difficulty interacting with the surrounding community. (iii) Government efforts in overcoming prostitution on Jl. Abu Bakar Lambogo is the rehabilitation that he has experienced is an effort to resocialization and further guidance.
\end{abstract}

Keywords: Criminology, Practice of Prostitution.

Abstrak. Penelitian ini bertujuan untuk mengetahui faktor penyebab perempuan menjajakan dirinya sebagai pekerja seks komersial, dampak yang ditimbulkan keberadaan pekerja seks komersial di wilayah Jl. Abu Bakar Lambogo serta bagaimana upaya pemerintah dalam penanggulangan prostitusi di Jl. Abu Bakar Lambogo. Jenis penelitian ini merupakan penelitian kualitatif yang bersifat deskriptif dengan menggunakan teknik pengumpulan data melalui observasi, wawancara dan dokumentasi. Teknik analisis data yang digunakan adalah secara kualitatif deskriptif. Analisis ini dilakukan dengan cara menyusun dan mereduksi data, mendisplay data yang dikumpulkan. Berdasarkan hasil penelitian yang diperoleh dapat disimpulkan bahwa (i) Faktor penyebab perempuan menjajakan dirinya sebagai pekerja seks komersial adalah factor lingkungan pergaulan yakni pergaulan bebas marak oleh karena tidak adanya pendidikan sehingga terjerumus pada pekerjaan sebagai PSK, factor ekonomi yakni kurangnya penghasilan dan lapangan pekerjaan yang sempit, factor factor broken home yakni tidak akurnya keluarga seperti pertengkaran dan semacamnya menyebabkan anak tidak terurus atau tidak adanya fungsi orang tua terhadap anak. (ii) Dampak yang ditimbulkan keberadaan pekerja seks komersial di wilayah Jl. Abu Bakar Lambogo ialah masyarakat setempat merasa resah dengan keberadaan PSK di lingkungan sekitar tempat tinggalnya dan Kesulitan berinteraksi dengan masyarakat sekitar. (iii) Upaya pemerintah dalam penanggulangan prostitusi di Jl. Abu Bakar Lambogo adalah rehabilitasi yang di dalamnya adalah upaya resosialisasi dan bimbingan lanjut.

Kata Kunci : Kriminologis, Praktik Prostitusi. 


\section{PENDAHULUAN}

Pekerja seks komersial adalah seseorang yang menjual jasanya untuk melakukan hubungan seksual untuk uang atau disebut pelacur. Pelacur adalah sebuah suatu perbuatan dimana seseorang perempuan menyerahkan dirinya untuk berhubungan dengan jenis kelamin lain dengan mengharapkan bayaran, baik berupa uang maupun bentuk lainnya. Menurut Alam A. S. (I Pebrianti 2014).

Upaya mencari penghasilan untuk sekarang ini tidaklah mudah karena lapangan kerja yang sangat terbatas disamping tingkat pendidikan yang sangant rendah. Dengan tingkat pendidikan yang rendah dan tidak adanya keterampilan yang mereka miliki menyebabkan mereka mencari jenis pekerjaan yang dengan cepat menghasilkan uang. Salah satu jalan pintas dalam perjalanan hidup seorang perempuan akibat cobaan-cobaan hidup yang berat dirasakan, perempuan tersebut terjun dalam dunia pelacuran.

Berdasarkan observasi awal yang dilakukan oleh peneliti pada wilayah kota Makassar jl. Abu bakar lambogo, sebagian masyarakat sekitar tidak banyak tahu tentang keberadaan PSK tersebut yang tinggal disekitar dipemukiman mereka. Ketika peneliti melakukan wawancara dengan salah satu warga setempat jl. Abu bakar lambogo yang jauh lebih mengetahui tentang keberadaan PSK tersebut disekitar pemukiman mereka. Dan hasil dari wawancara dengan salah satu warga setempat yaitu hasil dari wawancara tersebut telah ditemukan kost-kostan dimana rata-rata yang penghuni kost tersebut yaitu seorang pelaku para pekerja seks komersial atau biasanya disebut PSK.

Peneliti akan membedakan penelitian sebelumnya tentang praktek prostitusi yang lainnya, dan beberapa peneliti diantaranya: Penelitian pertama dilakukan oleh Penti Nur. Fakultas Hukum Universitas Hasanuddin Makassar, 2014 dengan judul 'Tinjauan Kriminologis Terhadap Prostitusi Berkedok Bisnis di Kota Makassar. Tujuan Penelitian ini untuk mengetahui Faktor-faktor yang melatar belakangi terjadinya Prostitusi berkedok bisnis dan Upaya penanggulangan dan Akibat Prostitusi berkedok bisnis di Kota Makassar.

Penelitian kedua dilakukan oleh "Jaringan Prostitusi Tretes Prigen Pasuruan" yang dilakukakan oleh Nur Khofifah UIN Sunan Ampel Surabaya, 2015. Tujuan penelitian ini untuk mengetahui peran masing-masing agen dalam jaringan prostitusi di Desa Tretes Kecamatan Prigen Kabupaten Pasuruan.

Penelitian ketiga "Dampak Lokalisasi Pekerja Seks Komersial 'PSK' Terhadap Masyarakat Sekitar" yang dilakukan oleh Astri Sandra Amalia, Fakultas IImu Sosial dan IImu Politik Universitas Mulawarman, 2013. Studi Kasus : Purwajaya Kab. Kutai Kartanegara. Penelitian ini bertujuan untuk mengetahui dan menggambarkan dampak yang ditimbulkan dari adanya tempat praktek prostitusi terhadap masyarakat sekitar Desa Purwajaya.

Berdasarkan penelitian-penelitian yang relevan diatas, peneliti mencoba untuk mengangkat judul yang bertema Tinjauan kriminologis terhadap kegiatan praktik prostitusi di kota Makassar. Perbedaan penelitian yang akan dilakukan ini dengan penelitian-penelitian yang relevan diatas adalah penelitian yang akan dilakukan peneliti akan lebih memfokuskan diri kepada pekerja seks komersial itu sendiri dan ditekankan sedikit oleh pemerintah bagaimana cara penanggulangan yang efektif agar praktik prostitusi, setidaknya bisa dikurangi atau dapat diminamalisir.

\section{LANDASAN TEORI}

Penulis dalam menganalis masalah penelitian menggunakan pendekatan beberapa teori. Teori kontrol sosial MK Darmawan (2014), Kontrol sosial baik personal kontrol maupun sosial kontrol menentukan seseorang dapat melakukan tindak pidana atau tidak karena pada keluarga atau masyarakat yang mempunyai sosial kontrol yang disiplin maka kemungkinan terjadinya suatu kejahatan akan kecil, begitu juga sebaliknya suatu keluarga atau masyarakat yang tidak mempunyai kontrol yang kuat maka kejahatan bisa saja mudah terjadi akibat dari tidak disiplinnya suatu kontrol tersebut. Teori tersebut adalah Kontrol sosial, fenomenolgis dan labeling. Pemilihan teori tersebut oleh karena menurut penulis relevan dalam penelitian ini. Alasan mendasarnya adalah, teori control 
sosial berhubungan dengan bagaimana peran lembaga baik keluarga maupun dalam masyarakat. Dalam konteks penelitian ini, penulis memiliki asumsi bahwa dimungkinkan tidak adanya control sosial sehingga muncuk eksistensi PSK dalam masyarakat.

$\checkmark$ Ambarwati (2012), Teori Fenomenologi konsep fenomenologi bermula dari pandangan Edmund Husserl yang meyakini bahwa sesungguhnya objek ilmu itu tidak terbatas pada hal-hal yang empirik, tetapi juga mencakup fenomena yang berada di luar itu seperti persepsi, pemikiran, kemauan dan keyakinan subyek tentang "sesuatu" di luar dirinya. Menurut pendapat Shaw, McKay dalam M Mulyadi (2009), bahwa di kampung-kampung yang berantakan dan tidak terorganisasi secara baik, perilaku jahat merupakan perilaku yang normal dan wajar. Teori ini dibangunnya berdasarkan pandangan bahwa setiap manusia cenderung untuk tidak patuh terhadap hukum atau memiliki dorongan untuk melakukan pelanggaran hukum. Oleh karena itu, para ahli teori menilai perilaku menyimpang merupakan konsekuensi logis dari kegagalan seseorang untuk mentaati hukum. Sedangkan teori fenomenologis, mengatakan bahwa manusia kecenderungan melakukan pelanggaran-pelanggaran aturan, begitupun juga dalam masalah penelitian ini.

Teori Labelling adalah sebuah definisi yang ketika di berikan kepada seseorang akan menjadi identitas diri orang tersebut, dan menjelaskan orang dengan tipe bagaimanakah dia. Dengan memberikan label pada diri seseorang, kita cenderung melihat dia secara keseluruhan kepribadiannya, dan bukan pada perilakunya satu persatu. Menurut, Lemert (dalam Sunarto, 2007), teori labelling adalah penyimpangan yang disebabkan oleh pemberian cap/ label dari masyarakat kepada seseorang yang kemudian cenderung akan melanjutkan penyimpangan tersebut. Sementara itu teori labeling adalah penamaan terhadap suatu hal, dalam konteks ini berlaku dalam menganalisis label perilaku PSK oleh masyarakat.

\section{METODE PENELITIAN}

Jenis penelitian yang digunakan adalah penelitian deskriptif kualitatif dengan pendekatan studi kasus. Menurut Cresswell (2012: 259), beberapa asumsi dalam pendekatan kualitatif yaituyang pertama, peneliti kualitatif lebih memerhatikan proses daripada hasil. Kedua, peneliti kualitatif lebih menekankan pada interpertasi. Ketiga, peneliti kualitatif merupakan alat utama dalam mengumpulkan data serta penelitian kualitatif harus terjun langsung kelapangan, untuk melakukan observasi partisipasi. Keempat, penelitian menggambarkan bahwa peneliti terlibat dalam proses penelitian, interpertasi data, dan pencapaian pemahaman melalui kata atau gambar. Terakhir, proses penelitian kualitatif bersifat induktif dimana peneliti membuat konsep, hipotesa atau dugaan sementara, dan teori berdasarkan data lapangan dalam proses penelitian.

Peneliti ini berusaha menggali fenomena dengan menggambarkan problematika yang terjadi tentang tinjauan kriminologis terhadap praktik prostitusi melalui di kota Makassar. Pengambilan informan menggunakan purposive sampling yakni pengambilan sampel yang sudah diketahui karakteristik atau ciri-cirinya. Pada penelitian ini, penulis sendiri yang instrument. Adapun jenis data yang digunakan dalam penelitian ini adalah subjek dari mana data dapat diperoleh. Dalam penelitian ini penulis menggunakan dua sumber data, yakni data primer dimana data yang di kumpulkan melalui obyek dan data sekunder dimana data yang diperoleh dari hasil-hasil penelitian yang relevan dan data yang tidak secara langsung diperoleh dari responden, tetapi diperoleh dengan menggunakan dokumen yang sangat erat hubungannya dengan pembahasan yang ada.

Teknik pengumpulan data yang dilakukan dengan menggunakan 3 cara dengan cara pengamatan, wawancara, dan telaah dokumentasi. Analisis data yang digunakan untuk menganalisis data yang digunakan dalam penelitian ini adalah analisis data deskriptif yaitu cara yang digunakan untuk menganalisis data dengan cara mendeskripsikan atau menggambarkan data yang telah terkumpul atau generalisasi. Adapun untuk keabsahan data dalam melakukan uji kredibilitas data atau kepercayaan dengan perpanjangan pengamatan, dan melakukan trianggulasi, baik dari trianggulasi waku, sumber dan juga teknik. 


\section{HASIL DAN PEMBAHASAN}

\section{Hasil dan Pembahasan}

1. Faktor Penyebab Perempuan Menjajakan Dirinya Sebagai Pekerja Seks Komersial Di Jl. Abu Bakar Lambogo

\section{a. Faktor Lingkungan Pergaulan}

Dari beberapa informasi yang disampaikan oleh beberapa informan di atas, terdapat factor yang yang melatar belakangi perempuan menjajakan dirinya sebagai pelaku seks komersial di Jl. Abu Bakar Lambogo kota Makassar, faktor tersebut adalah factor lingkungan pergaulan.

Menurut Kamus Besar Bahasa Indonesia kata "pekerja seks komersial" berasal dari kata dasar "pelacur" yang berarti malang, celaka, gagal, sial atau tidak jadi. jadi pekerja seks komersial adalah orang yang berbuat pelacuran atau orang menjual diri sebagai pekerja seks komersial. Sedangkan pemerintah lebih sering menggunakan untuk istilah pekerja seks komersial dengan nama atau pekerja seks komersial (psk). ini bisa jadi agar lebih "menghaluskan" makna dalam menyebutkan istilah pekerja seks komersia (KBBI:2014).

Ada banyak masalah yang ditemukan di lapangan oleh karena tidak mengenyam pendidikan, seperti maraknya pergaulan bebas di kalangan remaja. Merujuk pada pernyataan beberapa informan di atas, lingkungan pergaulan menjadi salah satu latar belakang atau factor yang menjadikannya sebagai pelaku seks komersial. Pergaulan bebas adalah salah satu bentuk perilaku menyimpang yang melewati batas kewajiban, tuntutan,aturan, syarat,dan perasaan malu. Pengertian pergaulan bebas di ambil dari kata Pergaulan yang artinya proses interaksi antar individu atau individu dengan kelompok, sedang kata Bebas yang artinya terlepas dari kewajiban, aturan, tuntutan, norma agama, dan pancasila.

Melihat realitas di atas eksistensi pendidikan sangat penting yakni memanusiakan manusia yang bertujuan menganalisis perkembangan dan kemajuan sosial. Pendidikan juga merupakan sebuah proses sehingga pendidikan dapat dijadikan instrumen oleh individu untuk berinteraksi secara tepat di komunitas dan masyarakatnya. Pendidikan diselenggarakan untuk manusia Indonesia, sehingga manusia Indonesia memiliki kemampuan mengembangkan diri, meningkatkan mutu kehidupan, meningkatkan martabat dalam rangka mencapai tujuan nasional. Oleh karena perilaku yang menyimpang

\section{b. Faktor Ekonomi}

Keberadaan prostitusi di Jl. Abu Bakar Lambogo kota Makassar, disebabkan oleh banyak factor, factor selanjutnya adalah factor ekonomi. Bicara tentang ekonomi, berarti domainnya adalah soal kebutuhan hidup. Di jaman sekarang sempitnya lapangan pekerjaan dan beberapa masalah lainnya membuat individu cenderung mengambil jalan yang singkat meski yang melanggar noma sekalipun.

Dalam dunia protitusi seperti dalam penelitian ini yang ada hal-hal yang menyebabkan terjadinya kegiatan tersebut, karena banyak orang-orang yang orientasi hidupnya pada materi. Terdapat banyak pelacuran yang telah berhasil mengumpulkan kekayaan di komunitas yang menghasilkan PSK, sehingga mereka yang berada di lokalisai dengan mudah dapat menemukan model yang diinginkan. (Koentjoro, 2004:135)

\section{c. Faktor Broken Home}

Terlahir dan tumbuh dalam lingkungan keluarga yang "broken" bukanlah menjadi sesuatu yang bisa dipilih. Mereka terbiasa dengan pertengkaran, suara yang lantang, kekerasan, 
ketidakharmonisan dan canggung menunjukkan kasih sayang. Seperti layaknya anak-anak lain yang mendambakan sebuah keluarga yang harmonis dan penuh kasih sayang, mereka pun menginginkannya.

Tidak adanya peran fungsional keluarga dalam kehidupan sehari hari membuat mereka dari keluarga yang tidak utuh, cenderung tertutup dan tidak mudah percaya dengan orang lain karena mereka sering merasa kecewa. Kecewa karena keluarga yang tidak harmonis, tidak ada penerimaan, kasih sayang, rasa nyaman, negosiasi, dan perlindungan. mereka sering merasa tidak stabil secara emosi. Ketidakstabilan emosi tersebut karena keadaan keluarga yang tidak hangat, orangtua bercerai dan tekanan atau pengabaian orangtua terhadap mereka.

Tidak optimalnya peran orang tua terhadap pertumbuhan anak sebagiannya menyebabkan mereka bebas dan tidak terurus. PSK yang diwawancarai pada beberapa waktu lalu mengaku stress dan kehilangan control diri. Dalam suatu interaksi mereka terjebak pada pergaulan yang salah sehingga ditemukan beberapa mereka menjadi PSK.

\section{Dampak Yang Dirasakan Warga Sekitar JI. Abu Bakar Lambogo Terhadap Kehadiran PSK}

\section{a. Meresahkan Warga}

Masyarakat di Jl. Abu Bakar Lambogo yang mengetahui seseorang di lingkungannya menjadi PSK, pada umumnya mereka akan mengucilkannya dan memberikan perlakuan yang tidak adil kepadanya. Masyarakat tidak hanya memandang rendah individu PSK yang ada tetapi mereka juga memandang rendah keluarga PSK tersebut(ayah/ibu) karena dianggap tidak dapat memberi didikan yang baik bagi anaknya. Namun ada juga beberapa masyarakat yang memandang bahwa para PSK itu sendiri tidak memahami kenapa jalan itu yang harus mereka pilih. Pelacur juga manusia, mereka punya hati, bahkan ada juga pelacur yang bisa lebih baik daripada orang yang mencemoohnya.

Sudah menjadi pengetahuan kita bersama, banyak sekali masyarakat yang mengucilkan PSK, dan hal itu juga berlaku bagi keluarga PSK tersebut. Masyarakat pun turut mengejek dan memandang rendah keluarga dari PSK itu, misalnyanya anak dari seorang PSK, anak seorang PSK akan dikucilkan oleh teman sebayanya, sebab orang tua dari anak-anak tersebut khawatir jika anaknya akan terpengaruh berbuat nistakarena mereka menganggap bahwa jika ibunya saja bekerja seperti itu maka anaknya pun juga akan begitu.

\section{b. PSK Kesulitan Berinteraksi dengan Masyarakat Sekitar}

Interaksi sosial merupakan hubungan-hubungan sosial yang menyangkut hubungan antarindividu, individu (seseorang) dengan kelompok, dan kelompok dengan kelompok.

Tanpa adanya interkasi sosial maka tidak akan mungkin ada kehidupan bersama. Proses sosial adalah suatu interaksi atau hubungan timbal balik atau saling mempengaruhi antar manusia yang berlangsung sepanjang hidupnya didalam amasyarakat. Menurut Soerjono Soekanto, proses sosial diartikan sebagai cara-cara berhubungan yang dapat dilihat jika individu dan kelompok-kelompok sosial saling bertemu serta menentukan sistem dan bentuk hubungan sosial.

Sebagian besar masyarakat di Jl. Abu Bakar Lambogo menganggap PSK itu hina, tentu PSK akan berpikir orang-orang disekitarnya memusuhi dan mengucilkannya, sehingga PSK merasa takut untuk berinteraksi dengan masyarakat sekitar yang dianggapnya tidak menerima eksistensinya di tengah masyarakat akibat status pekerjaannya.

Menurut Koentjoro, (1996) wanita pekerja seks komersial selalu mengalami konflik dalam dirinya, baik konflik kepentingan antara rasa membutuhkan uang dan perasaan berdosa, atau juga karena adanya perasaan tidak aman akan statusnya sebagai pekerja seks komersial dalam 
masyarakat. Hubungan seksual yang normal mengandung pengertian :hubungan itu tidak menimbulakn efek-efek merugikan, tidak menimbulkan konflik-konflik psikis dan tidak ada paksaan. Dengan begitu hubungan seks hendaknya dilakuakan dalam suatu ikatan yang teratur yaitu perikahan (Kartini, kartono: 1992).

Dapat disimpulkan dengan realitas yang terjadi pada diri PSK di di Jl. Abu Bakar Lambogo, mereka memiliki konflik internal atas apa yang telah terjadi dengan kehidupannya. Di satu sisi mereka melakukannya untuk memenuhi kebutuhan hidup dan sisi lain perbuatan tersebut berisiko yakni mendpat cemoohan dari masyarakat sekitar.

Jika proses interaksi sosial tidak terjadi secara maksimal seperti yang dialami oleh PSK di Jl. Abu Bakar Lambogo menyebabkan terjadinya kehidupan yang terasing. Faktor yang menyebabkan kehidupan terasing misalnya sengaja dikucilkan dari lingkungannya, mengalami cacat, pengaruh perbedaan ras dan perbedaan budaya.

\section{Upaya Pemerintah Dalam Penanggulangan Prostitusi Di Jl. Abu Bakar Lambogo}

Untuk mengatasi masalah tersebut, Pemerintah Indonesia mendirikan Pusat Pelayana Sosial Karya Wanita yang tersebar di seluruh Indonesia, salah satunya di kota Makassar yang bergerak dalam bidang rehabilitasi para WTS (Wanita Tuna Susila).

\section{a. Pola Rehabilitasi}

Rehabilitasi itu sendiri sesuai Undang-Undang Kesejahteraan Sosial Nomor 11 tahun 2009 tentang Kesejahteraan Sosial, khususnya pada pasal 7 ayat 1 di sebutkan bahwa: "Rehabilitasi sosial dimaksudkan untuk memulihkan dan mengembangkan kemampuan seseorang yang mengalami disfungsi sosial agar dapat melaksanakan fungsi sosialnya secara wajar".

Menurut Jurnal Kementerian Sosial Vol 3 Tahun 2008, rehabilitasi sosial adalah proses refungsionalisasi dan pengembangan untuk memungkinkan seseorang mampu melaksanakan fungsi sosialnya secara wajar dalam kehidupan masyarakat.

Rehabilitasi Sosial yang digunakan oleh Pusat Pelayanan Sosial Karya Wanita Mattirodeceng yaitu: Bimbingan Sosial, bimbingan fisik, bimbingan mental, dan bimbingan vokasional. Rehabilitasi sosial dimaksudkan dalam kaitannya dengan layanan kepada klien yang membutuhkan layanan khusus di bidang sosial, yaitu meningkatkan kemampuan bersosialisasi, mencegah agar kemampuan sosialnya tidak menurun atau lebih parah dari kondisi sosial sebelumnya.

\section{b. Pola Resosialisasi}

Resosialisasi merupakan proses pembelajaran norma baru, nilai, sikap, dan perilaku. Sebagian besar resosialisasi bersifat sukarela tetapi beberapa di antaranya, seperti yang terjadi pada penghuni institusi total, tidak bersifat sukarela. Institusi total sebagai suatu tempat tinggal dan bekerja yang di dalamnya terdapat sejumlah individu dengan situasi yang sama, terputus dari masyarakat yang lebih luas untuk jangka waktu tertentu, bersama-sama menjalankan kehidupan yang terkungkung dan diatur secara formal.

Informasi di atas menunjukkan bahwa bimbingan sosial bertujuan untuk memberikan kepada klien untuk hidup dengan baik. Menjelankan fungsi sosial dan bertanggung jawab untuk diri sendiri maupun lingkungannya. Menjalin hubungan dan kerjasama yang baik dengan keluarga maupun masyarakat di sekitarnya. 


\section{c. Bimbingan Lanjut}

Menurut Kementerian Sosial Republik Indonesia mengemukakan bahwa bimbingan lanjut merupakan rangkaian kegiatan penyelenggaraan kesejahteraan sosial sebagai upaya untuk lebih memantapkan kemandirian klien, baik berupa konsultasi,bantuan ulang, bimbingan peningkatan atau pengembangan dan pemasaran maupun petunjuk lain untuk memperkuat kondisi kehidupan bermasyarakat.

Bimbingan yaitu sesuatu yang menyangkut batin dan watak manusia, yang bukan bersifat badan atau tenaga, bukan hanya pembangunan fisik yang di perhatikan, melainkan juga pembangunan psikis. Disini mental di hubungkan dengan akal, fikiran dan ingatan, maka akal haruslah di jaga dan di pelihara oleh karena itu dibutuhkan mental yang sehat.

Pelaksanaan program kegiatan keterampilan-ketarmpilan dan bimbingan bimbingan di PPSKW "Mattirodeceng" mempunyai dampak yang positif bagi mereka para klien. Perubahan dari diri klien saat mengikuti berbagai pelaksanaan kegiatan keterampilan-keterampilan yang di berikan oleh PSKW "Mattirodeceng" adalah mereka mampu membuat atau berkreasi dari keterampilan yang mereka pilih. Selain dari keterampilannya, para klien juga menjadi lebih bermoral lagi karena adanya bimbingan-bimbingan dari PSKW "Mattirodeceng".

\section{KESIMPULAN}

Berdasarkan hasil penelitian dan pembahasan atas data yang berhasil dihimpun tentang tinjauan kriminologis terhadap kegiatan praktik prostitusi di kota Makassar maka dapat diperoleh simpulan sebagai berikut :

Pekerja seks komersial adalah seseorang yang menjual jasanya untuk melakukan hubungan seksual untuk uang atau disebut pelacur. Pekerja seks komersial di Jl. Abu Bakar Lambogo, eksistensinya menuai banyak protes dari warga setempat dengan dasar pertimbangan yang rasionalitas. Maka dari itu, berikut penulis menyimpulkan sebagai berikut:

1. Faktor Penyebab Perempuan Menjajakan Dirinya Sebagai Pekerja Seks Komersial, faktor lingkungan pergaulan, faktor ekonomi dan faktor Broken Home.

2. Dampak Yang Ditimbulkan Keberadaan Pekerja Seks Komersial di Wilayah Jl. Abu Bakar Lambogo, ada beberapa dampak yaitu: (a) Meresahkan masyarakat; reaksi sosial masyarakat terhadap pekerja seks komersial di Jl. Abu Bakar Lambogo, terlihat bahwa ada anggota masyarakat yang menolak kehadiran PSK ini ditengah-tengah mereka. Hal ini dikarenakan mereka merasa jijik dan takut tertular oleh penyakit menular seksual yang bisa saja dibawa oleh PSK ini. Kemudian anggota masyarakat merasa lingkungan tempat tinggalnya tercemar nama baiknya karena keberadaan wanita psk di tengah-tengah mereka. (b) Kesulitan berinteraksi dengan masyarakat sekitar; Karena sebagian besar masyarakat menganggap PSK itu hina, tentu PSK akan berpikir orang-orang disekitarnya memusuhi dan mengucilkannya, sehingga PSK merasa takut untuk berinteraksi dengan masyarakat sekitar yang dianggapnya tidak menerima eksistensinya di tengah masyarakat akibat status pekerjaannya.

3. Upaya Pemerintah dalam Penanggulangan Prostitusi di Jl. Abu Bakar Lambogo; Beberapa upaya yang dilakukan oleh pemerintah setempat adalah kegiatan rehabilitas sosial yang digunakan Pusat Pelayanan Sosial Karya Wanita (PPSKW) "Mattirodeceng" Kota Makassar di dalamnya ada upaya resosialisasi dan bimbingan lanjut. 


\section{DAFTAR PUSTAKA}

Jurnal Kementerian Sosial Vol 3 Tahun 2008

Pusat Penelitian dan Pengembangan Bahasa, Kamus Besar Bahasa Indonesia (KBBI) Cet III, (Jakarta: Balai Pustaka, 2014), h. 57.

Amalia, Astry Sandra. (2013). “Dampak Lokalisasi Pekerja Seks Komersial (PSK) Terhadap masyarakat sekitar (Studi kasus di jalan Soekarno-Hataa Km. 10 Desa Purwajaya Kabupaten Kutai Kartanegara)." Jurnal administrasi Negara

Anwar Yemil. (2009). Saat Memuai Kejahatan, Sebuah Pendekatan Sosiokultural Kriminologi, Hukum dan HAM. PT Refika Aditama, Bandung. HIm. 29

Amalia, Mia. (2018). Analisis Terhadap Tindak Pidana Prostitusi Dihubungkan Dengan Etika Moral Serta Upaya Penanggulangan Di Kawasan Cisarua kampong Arab. Jurnal hukum mimbar Justia2.2.

Andi Hamzah. (2008). Terminology Hukum Pidana. Sinar Grafika: Jakarta hlm. 48

Darmawan, M.Kema. (2014). Teori Kriminologi. Sinar Grafika: Jakarta

Enjang Gumelar, Yunis Effendri. (2017). Pelanggaran Prinsip Kerja Sama Grice Dalam Pertuturan Interaksional Gigolo di Surabaya. BAPALA 4.2

Emzir. (2010). Metodologi Penelitian Kualitatif: Analisis Data. Rajawali Pers: Jakarta Fathonah, Rini. (2016). Analisis Terhadap Factor Penyebab Prostutusi Anak. Jurnal Poenalo 3.4 Faida, Riza. (2011). Analisis Kebutuhan Pada Mahasiswa Yang Melakukan Seks Bebas Berdasarkan EPPS. DISS. University Of Muhammadiyah Malang

Irwansyah, Litfi. (2016). Kemiskinan, Keluarga Dan Prostitusi Pada Remaja. Seminar Asean 2nd Psycology \& Humanity Psycology Forum UMM

Irana, F. (2017). Metode Penelitian Terapan. Parama Ilmu: Yogyakarta

Ilyas, Amir. (2012). Asas-Asas Hukum Pidana, Memahami Tindak Pidana dan Pertanggungjawaban Pidana Sebagai Syarat Pemidanaan. Rangkang Education Ida, R. (2014). Metode Penelitian: Studi Media Dan Kajian Budaya. Kencana Ikbal, Y. (2012). Metode Penelitian Sosial Kualitatif. Rafika Aditama: Bandung Khofifah, Nur. (2015). Jaringan Prostitusi Tretes Prigen Pasuruan. Diss. UIN Sunan Ampel Surabaya. 